\title{
DISTRIBUTION OF SPERMATOZOA IN THE OVIDUCT AND FERTILITY IN DOMESTIC BIRDS
}

\author{
IV. FERTILITY OF SPERMATOZOA FROM INFUNDIBULAR \\ AND UTEROVAGINAL GLANDS
}

\author{
H. P. VAN KREY*, F. X. OGASAWARA AND F. W. LORENZ \\ University of California, Davis, California, U.S.A.
}

(Received 9th August 1965)

\begin{abstract}
Summary. Intramagnal insemination by a procedure which caused the deposition of large numbers of spermatozoa in infundibular glands but few or none in uterovaginal glands, resulted in prolonged fertility with an exceptionally high incidence of pre-oviposital embryonic mortality, as compared with the fertility resulting from insemination by techniques which deposited spermatozoa primarily in the uterovaginal glands.
\end{abstract}

\section{INTRODUCTION}

The presence of sperm-containing tubular glands in the uterovaginal junction of the chicken was reported by Bobr, Lorenz \& Ogasawara (1962, 1964a) and by Fujii (1963) and Fujii \& Tamura (1963). An examination of spermatozoan distributions following artificial insemination (A.I.) led Bobr, Ogasawara \& Lorenz (1964b) to conclude that these uterovaginal glands were the principal sites for oviducal storage of spermatozoa, rather than the infundibular 'sperm nests' previously reported by Van Drimmelen (1946). Histological preparations following A.I. generally revealed very few or, more commonly, no spermatozoa in infundibular glands, whereas uterovaginal glands from the same oviducts always contained spermatozoa throughout the fertile period; these have ordinarily been present in large numbers for several days after A.I.

The functional significance of the few spermatozoa that are found in infundibular glands, especially after repeated copulation (Fujii \& Tamura, 1963), has not been satisfactorily determined. Large numbers were found in these glands following intra-uterine A.I. (Bobr et al., 1964a) demonstrating their capacity for spermatozoa storage, but, since the same birds had uterovaginal glands engorged with spermatozoa, the fertilizing capacity of spermatozoa from infundibular glands was not determined. The discovery of a method of filling infundibular glands, while leaving the uterovaginal glands empty, led to experiments described herein and designed to compare the roles of infundibular and uterovaginal glands in the maintenance of fertility in the hen. 


\section{MATERIAL AND METHODS}

All experimental birds were adult single comb White Leghorns, maintained in individual cages. Semen donors were all cocks of proven fertility. Semen was collected by the abdominal massage method of Burrows \& Quinn (1935), as modified by Lake (1957), to prevent contamination of the semen with lymphatic fluid. Females were also of 'proven fertility' as determined by the production of at least five successive fertile eggs following an intravaginal A.I. Residual fertility was ruled out by the laying of at least three consecutive infertile eggs before any fertility experiment was begun.

To eliminate possible effects of individual males on the fertility patterns, undiluted pooled semen $(0.05 \mathrm{ml})$ was used for all inseminations. Four methods of A.I. were employed: (1) midvaginal: according to the technique originally described by Munro (1935) and by Quinn \& Burrows (1936); (2) anterior vaginal: a technique described by Bobr, Lake, Lorenz, Ogasawara \& Krzanowska (1965) that employs prolonged gentle pressure to exaggerate vaginal eversion, was used to expose the uterovaginal junction and semen was deposited thereon; (3) intra-uterine: the uterovaginal junction was exposed by the same technique as in (2) and penetrated with a special pipette attached to a syringe to deposit semen in the uterine lumen; and (4) intramagnal: the magnum was exposed through a short mid-abdominal incision following intravenous sodium pentobarbital anaesthesia, and punctured with a 22-gauge needle through which semen was introduced into the lumen. All the hens subjected to intramagnal A.I. had hard-shelled eggs in the uterus; such hens were chosen to ensure that there would be no interfering egg in the magnum, but this choice had the unexpected result to be described.

Bobr et al. (1964a) and Ogasawara, Lorenz \& Bobr (1966) described the distributions of spermatozoa in oviduct glands following intravaginal and intra-uterine A.I. ; in the present investigation eight hens were examined for spermatozoan distributions 1 to 5 days after intramagnal A.I. by the procedure described in the latter paper.

Fertility was determined in experiments 1 to 4 by macroscopic examination of the blastodisks of eggs opened after $24 \mathrm{hr}$ of incubation. In Experiment 5, unincubated blastodisks were examined macroscopically and all except obviously fertile ones were also examined microscopically after superficial staining, i.e. by the Kosin test (Kosin, 1944). In Experiment 6 the eggs were also examined without being incubated, but the blastodisks of all, except the obviously fertile eggs, were serially sectioned from paraffin blocks, stained with haematoxylin and eosin, and searched for cell nuclei at $\times 400$ magnification (Kosin, 1945; Munro \& Kosin, 1945).

Differences between appropriate egg production figures and fertility percentages (the latter after conversion to angles) were tested for statistical significance by the modified Duncan's multiple range test (Duncan, 1955). Calculated probability ranges appear in footnotes to the tables.

\section{RESULTS}

The hens subjected to intramagnal A.I. all oviposited prematurely, either during or immediately after the anaesthetic was administered; in the eight birds killed 
for oviduct examination almost all of the spermatozoa were found to have migrated anteriorly. A few spermatozoa were found in the uterovaginal glands of only two hens: in a single gland of one and in five glands of another. By contrast, the infundibular glands of all hens were extraordinarily engorged. In one hen, for example, killed 2 days after intramagnal A.I., 959 glands containing spermatozoa were counted in a single longitudinal section; $79 \%$ of these contained more than ten spermatozoa and many contained large masses, probably of a hundred or more. These results may be compared to those of Ogasawara et al. (1966) following intra-uterine A.I., where comparatively few infundibular glands contained spermatozoa and very few if any contained as many as ten.

\section{TABLE 1}

FERTILITY FOLLOWING VARIOUS ROUTES OF INSEMINATION, AS DETERMINED BY MACROSCOPIC EXAMINATION OF BLASTODISKS OF EGGS INGUBATED 24 HOURS (0.05 ML UNDILUTED SEMEN)

\begin{tabular}{|c|c|c|c|c|c|c|}
\hline \multirow[b]{2}{*}{ A.I. route } & \multirow{2}{*}{$\begin{array}{l}\text { No. } \\
\text { hens }\end{array}$} & \multirow{2}{*}{$\begin{array}{l}\text { Eggs laid, } \\
\text { Days } 2 \text { to } 22 \\
\text { (average } \\
\text { no./hen) }\end{array}$} & \multicolumn{3}{|c|}{ Fertility of eggs laid $(\%)$} & \multirow{2}{*}{$\begin{array}{c}\text { Fertility } \\
\text { average } \\
\text { duration } \\
\text { (days) }\end{array}$} \\
\hline & & & $\begin{array}{l}\text { Days } \\
2 \text { to } 8\end{array}$ & $\begin{array}{c}\text { Days } \\
9 \text { to } 15\end{array}$ & $\begin{array}{c}\text { Days } \\
16 \text { to } 22\end{array}$ & \\
\hline $\begin{array}{l}\text { Midvaginal } \\
\text { Anterior vaginal } \\
\text { Intra-uterine } \\
\text { Intramagnal }\end{array}$ & $\begin{array}{l}20 \\
20 \\
20 \\
30\end{array}$ & $\begin{array}{c}13 \cdot 6 \\
13 \cdot 4 \\
12 \cdot 6 \\
7 \cdot 2 *\end{array}$ & $\begin{array}{l}89 \cdot 3 \\
91 \cdot 6 \\
89 \cdot 4 \\
47 \cdot 7^{*}\end{array}$ & $\begin{array}{l}51 \cdot 7 \\
60 \cdot 2 \\
67 \cdot 5 \\
68 \cdot 1\end{array}$ & $\begin{array}{c}9 \cdot 6 \\
4 \cdot 7 \\
5 \cdot 7 \\
41 \cdot 7 *\end{array}$ & $\begin{array}{l}13 \cdot 2 \\
13 \cdot 1 \\
13 \cdot 0 \\
18 \cdot 8^{*}\end{array}$ \\
\hline
\end{tabular}

* Egg production, percentage fertility in first and third periods and duration of fertility following intramagnal A.I. differed significantly $(P<0.01)$ from corresponding values following other A.I. methods. For all corresponding comparisons among other methods, $P>0.05$.

Table 1 shows fertility patterns, following A.I. by intramagnal and other routes, compared in four replicated experiments. Groups of five hens each were inseminated in each replicate, except that ten were used for intramagnal A.I. in each of the last two because of the depressing effect of this technique on egg production (Table 1). Most birds paused in egg production for varying periods after intramagnal A.I., but were nearly back to normal by the third week. Apparent fertility, determined by incubating eggs for $24 \mathrm{hr}$, also differed strikingly between intramagnal A.I. and insemination by other routes. Only about half as many fertile blastodisks could be identified in eggs laid during the first week by the former hens. Fertility was more persistent in these hens, however; the average was prolonged nearly 6 days, and percentage fertility was nearly as high during the third week as during the first.

Although examination of incubated eggs is the method of choice for detecting viable embryos, it is not suitable for detecting pre-oviposital dead embryos. The abnormal fertility pattern described above suggested the need for taking these into account. Accordingly, a fifth experiment was performed, with fertility determined by examination of unincubated eggs, and the Kosin test when needed. In the first and second weeks, fertility estimates of the hens that received intramagnal A.I. were strikingly increased, as recorded in Table 2, suggesting a high incidence of pre-oviposital dead embryos in eggs from these 
birds. These did not completely account for the low first-week fertility by the intramagnal route, however; consequently, a sixth experiment was performed in which midvaginal and intramagnal routes of A.I. were compared in unincubated eggs, and all except the obviously fertile blastodisks were sectioned and stained as described above. The results (Table 3) demonstrate additional fertility, uncovered by this technique, that was otherwise not apparent because of the earliness of embryonic death. Appreciable numbers of these very early dead embryos occurred throughout the experimental period after intramagnal A.I.; they were present in sufficient numbers in eggs laid during the first week to account for the abnormality of the apparent fertility pattern as characterized by less precise methods. This technique also uncovered persistent fertility into the third week at levels higher than ordinarily observed.

TABLE 2

FERTILITY FOLLOWING VARIOUS ROU'TES OF INSEMINATION AS DETERMINED BY EXAMINATION OF UNINGUBATED BLASTODISKS WITH AID OF THE KOSIN TEST $(0.05$ ML UNDILUTED SEMEN)

\begin{tabular}{|c|c|c|c|c|c|c|}
\hline \multirow[b]{2}{*}{ A.I. route } & \multirow{2}{*}{$\begin{array}{l}\text { No. } \\
\text { hens }\end{array}$} & \multirow{2}{*}{$\begin{array}{c}\text { Eggs laid, } \\
\text { Days } 2 \text { to } 22 \\
\text { (average } \\
\text { no./hen) }\end{array}$} & \multicolumn{3}{|c|}{ Fertility of eggs laid $(\%)$} & \multirow{2}{*}{$\begin{array}{c}\text { Fertility } \\
\text { average } \\
\text { duration } \\
\text { (days) }\end{array}$} \\
\hline & & & $\begin{array}{l}\text { Days } \\
2 \text { to } 8\end{array}$ & $\begin{array}{c}\text { Days } \\
9 \text { to } 15\end{array}$ & $\begin{array}{c}\text { Days } \\
16 \text { to } 22\end{array}$ & \\
\hline $\begin{array}{l}\text { Midvaginal } \\
\text { Anterior vaginal } \\
\text { Intra-uterine } \\
\text { Intramagnal }\end{array}$ & $\begin{array}{r}5 \\
5 \\
5 \\
10\end{array}$ & $\begin{array}{c}14 \cdot 4 \\
16 \cdot 2 \\
11 \cdot 2 \\
5 \cdot 8 \dagger\end{array}$ & $\begin{array}{c}100 \cdot 0 \\
92 \cdot 3 \\
95 \cdot 0 \\
75 \cdot 0 \ddagger\end{array}$ & $\begin{array}{l}64 \cdot 3 \\
48 \cdot 3 \\
83 \cdot 3 \\
86 \cdot 0\end{array}$ & $\begin{array}{c}0 * \\
7 \cdot 6 \\
22 \cdot 2 \\
37 \cdot 0\end{array}$ & $\begin{array}{l}12 \cdot 4 \\
13 \cdot 0 \\
13 \cdot 4 \\
21 \cdot 7 \%\end{array}$ \\
\hline
\end{tabular}

* Fertility during the final period following midvaginal A.I. was significantly less than following other A.I. methods at $0.05>P>0.01$.

$\uparrow$ Egg production following intramagnal A.I. differed significantly from that following A.I. by either vaginal route at $P<0.01$, and following intra-uterine A.I. at $P=0.01$ to 0.05 .

$\ddagger$ Fertility during the first period and duration of fertility following intramagnal A.I. differed significantly from corresponding values following A.I. by other methods at $P<0.01$.

\section{DISCUSSION}

The results of the experimental inseminations, described above, exhibit two striking differences-in duration of fertility and in incidence of pre-oviposital mortality-depending on the A.I. site. These results draw immediate attention to the infundibulum, since the new and unexpected features were observed following intramagnal A.I., by which spermatozoa were deposited exclusively in infundibular glands. A.I. into other sites resulted in fertility patterns in accord with previous observations (see Lorenz, 1959, 1964, for reviews), i.e. high fertility during the first week, with subsequent rapid decline, nearly always terminating during or shortly after the end of the second week. Also, embryonic mortality has commonly been seen to increase sharply in eggs laid toward the end of the fertile period, and, again, although the results reported here are not entirely comparable, a striking increase in pre-oviposital mortality was observed during the third week after midvaginal A.I. : $19 \cdot 5 \%$ of all eggs laid, compared to $3.9 \%$ earlier (Table 3 ). 
Intramagnal A.I. resulted in a longer fertility span than has been found previously. This effect was almost certainly a consequence of the large numbers of spermatozoa deposited in the infundibulum rather than of special properties of the infundibular glands, since intra-uterine A.I., which also deposits spermatozoa in the infundibulum (though in more moderate numbers), resulted in no greater duration of fertility than did A.I. techniques that direct spermatozoa primarily to the uterovaginal glands.

The effect of intramagnal A.I. on pre-oviposital embryonic mortality was probably more complex, although the large numbers of spermatozoa in the infundibulum may have played a role here also. If the engorged glands released spermatozoa in such large numbers that polyspermy was a frequent consequence, this would have resulted in a significant number of nonviable embryos. Also, since spermatozoa degenerate rapidly after release (Bobr et al., 1964b) such

TABLE 3

FERTILITY FOLLOWING MIDVAGINAL AND INTRAMAGNAL A.I. AS DETERMINED IN SERIALLY SECTIONED BLASTODISKS (12 HENS/GROUP-0.05 ML UNDILUTED SEMEN)

\begin{tabular}{|c|c|c|c|c|c|c|}
\hline & \multicolumn{3}{|c|}{ Midvaginal A.r. } & \multicolumn{3}{|c|}{ Intramagnal A.1. } \\
\hline & $\begin{array}{c}\text { Days } \\
2 \text { to } 8 *\end{array}$ & $\begin{array}{c}\text { Days } \\
9 \text { to } 15\end{array}$ & $\begin{array}{c}\text { Days } \\
16 \text { to } 22\end{array}$ & $\begin{array}{l}\text { Days } \\
2 \text { to } 8\end{array}$ & $\begin{array}{c}\text { Days } \\
9 \text { to } 15\end{array}$ & $\begin{array}{l}\text { Days } \\
16 \text { to } 22\end{array}$ \\
\hline $\begin{array}{l}\text { Total eggs laid } \\
\text { Fertile eggs }(\%) \\
\text { Fertile eggs scored infertile }(\%) \\
\text { Apparent fertility }(\%)\end{array}$ & $\begin{array}{r}51 \\
86 \cdot 3 \\
3 \cdot 9 \\
82 \cdot 4\end{array}$ & $\begin{array}{r}51 \\
49 \cdot 0 \\
3 \cdot 9 \\
45 \cdot 1\end{array}$ & $\begin{array}{l}41 \\
22 \cdot 0 \\
19 \cdot 5 \\
2 \cdot 5\end{array}$ & $\begin{array}{l}20 \\
85 \cdot 0 \\
25 \cdot 0 \\
60 \cdot 0\end{array}$ & $\begin{array}{l}40 \\
82 \cdot 5 \\
17 \cdot 5 \\
65 \cdot 0\end{array}$ & $\begin{array}{l}40 \\
72 \cdot 5 \\
50 \cdot 0 \\
22 \cdot 5\end{array}$ \\
\hline
\end{tabular}

* Interval after A.I.

large numbers released in the infundibulum would have increased the probability of fertilization by degenerating spermatozoa. The possibility of the existence of either mechanism is supported by the observation that the incidence of mortality was highest soon after A.I., when the largest numbers of spermatozoa were present.

An alternative hypothesis involves the possible existence of a sperm-selection mechanism, operating in the uterovaginal glands, in the uterovaginal junction and/or in the transport mechanism up the length of the oviduct, but not in the infundibular glands. Such a mechanism was postulated by Allen \& Bobr (1955), who found that spermatozoa handicapped by admixture with glycerol failed to fertilize after being deposited in the vagina, but produced some fertility (with unknown embryonic consequences) after deposition in the uterus. Similarly, Ogasawara et al. (1966) found that semen from two lowfecundity cocks deposited in the vagina fertilized very few eggs, but that most of these few hatched. When A.I. was into the uterus, fertility was considerably increased, but nearly all of the increase was accounted for by pre-oviposital dead embryos. These results pointed to the existence of selection by a mechanism other than sperm transport, since spermatozoa introduced into the uterus still had to traverse most of the oviduct. They did not rule out such a mechanism, however, and high-fecundity semen has produced abnormal embryo mortality 
only when introduced high in the oviduct. Actually, several or all of the mechanisms described above may have played roles in the observed pre-oviposital mortality.

Nothing is known of differences in the physicochemical environments supplied by the two sets of glands, which might affect their abilities to maintain the viability of spermatozoa, but this subject is now under active investigation. The remarkable similarity of the average $\mathrm{pH}$ of the oviduct lumen in the two sperm-storage regions (Ogasawara, Van Krey \& Lorenz, 1964) suggests indirectly that the two sets of glandular environments may resemble each other more than they resemble other oviduct regions.

\section{ACKNOWLEDGMENTS}

This investigation was supported in part by a National Science Foundation Grant (GB-446) and in part by a Public Health Service training grant (GM646) from the Institute of General Medical Sciences. We are greatly indebted to Mrs A. R. Lester for skilled technical assistance.

\section{REFERENGES}

Allen, T. E. \& BoBR, L. W. (1955) The fertility of fowl spermatozoa in glycerol diluents after intrauterine insemination. Poult. Sci. 34, 1167.

Bobr, L. W., Lake, P. E., Lorenz, F. W., Ogasawara, F. X. \& Krzanowska, H. (1965) Inhibition of ovulation in the domestic hen by intrauterine insemination. Poult. Sci. 44, 659.

Bobr, L. W., Lorenz, F. W. \& Ogasawara, F. X. (1962) The role of the uterovaginal junction in storage of cock spermatozoa. (Abstract). Poult. Sci. 41, 1628.

Bobr, L. W., Lorenz, F. W. \& Ogasawara, F. X. (1964a) Distribution of spermatozoa in the oviduct and fertility in domestic birds. I. Residence sites of spermatozoa in fowl oviducts. 7. Reprod. Fert. 8, 39.

Bobr, L. W., Ogasawara, F. X. \& Lorenz, F. W. (1964b) Distribution of spermatozoa in the oviduct and fertility in domestic birds. II. Transport of spermatozoa in the fowl oviduct. $\mathcal{J}$. Reprod. Fert. $8,49$.

Burrows, W. H. \& Quin, J. P. (1935) A method of obtaining spermatozoa of the domestic fowl. Poult. Sci. 14, 251.

Duncan, D. B. (1955) Multiple range and multiple F tests. Biometrics, 11, 1.

FujIr, S. (1963) Histological and histochemical studies on the oviduct of the domestic fowl with special reference to the region of the uterovaginal juncture. Archum. histol. jap. 23, 447.

Fujir, S. \& Tamura, T. (1963) Location of sperms in the oviduct of the domestic fowl with special reference to storage of sperms in the vaginal gland. F. Fac. Fish. Anim. Husb. Hiroshima Univ. 5, 145.

Kosin, I. L. (1944) Macro- and microscopic methods of detecting fertility in unincubated hen's eggs. Poult. Sci. 23, 266.

Kosin, I. L. (1945) Abortive parthogenesis in the domestic fowl. Anat. Rec. 91, 245.

LAKE, P. E. (1957) Fowl semen as collected by the massage method. f. agric. Sci. 49, 120.

LoRenz, F. W. (1959) Reproduction in the domestic fowl. Physiology of the male. Reproduction in Domestic Animals, vol. 2, chap. I1, p. 343. Eds. H. H. Cole and P. T. Cupps. Academic Press, New York.

Lorenz, F. W. (1964) Recent research on fertility and artificial insemination of domestic birds. Proc. Vth int. Cong. Animal Reproduction and Artificial Insemination, Trento, Italy, 4, 7.

Munro, S. S. (1935) Motility and fertilizing capacities of fowl sperm in the excretory ducts. Proc. Soc. exp. Biol. Med. 33, 255.

Munro, S. S. \& Kosin, I. L. (1945) Proof of the existence of pre-oviposital embryonic deaths in chickens and their bearing on the relation between "fertility" and "hatchability." Can. F. Res. 23, 129.

Ogasawara, F. X., Lorenz, F. W. \& Bobr, L. W. (1966) Distribution of spermatozoa in the oviduct and fertility in domestic birds. III. Intra-uterine insemination of semen from low-fecundity cocks. 7. Reprod. Fert. 11, 33.

Ogasawara, F. X., Van Krey, H. P. \& Lorenz, F. W. (1964) Hydrogen ion concentration of the oviduct of the laying domestic fowl. Poult. Sci. 43, 3.

Qunn, J. P. \& Burrows, W. H. (1936) Artificial insemination in fowls. F. Hered. 27, 31.

VAn Drimmelen, G. C. (1946) "Spermnests" in the oviduct of the domestic hen. $\mathcal{F l} S$. Afr. vet. med. Ass. 17, 42. 